\title{
LA PRIMERA ESTANCIA DEL CARDENAL BELLUGA EN ROMA Y LA RENUNCIA AL OBISPADO DE CARTAGENA (1721-1723)
}

\section{Cardinal Bellugás first stay in Rome and the resignation of the bishopric of Cartagena (1721-1723)}

\author{
Maximiliano BARRIO GOZALO \\ Universidad de Valladolid \\ barrio@fyl.uva.es
}

Fecha de recepción: 25/09/2020

Fecha de aceptación definitiva: 16/04/2021

RESUMEN: A pesar de los muchos estudios que se han publicado sobre el cardenal Belluga, todavía hay algunos aspectos de su vida romana que se pueden y deben completar y precisar con la rica documentación que se conserva en el Archivo General de Simancas, apenas consultada. No obstante, en este artículo me limito a examinar dos temas de su primera estancia romana: la gestión para conseguir la bula de reforma del clero español y la larga y sinuosa negociación de su renuncia al obispado de Cartagena.

Palabras clave: cardenal Belluga; obispado de Cartagena; reforma del clero español; renuncia al obispado.

ABSTRACT: Despite the many studies that have been published on Cardinal Belluga, there are still some aspects of his Roman life that can and should be completed and specified with the rich documentation that is preserved in the General Archive of Simancas, just consulted. However, in this article I limit myself to examining two themes of his first Roman stay: the management to achieve the reform bull of the Spanish clergy, and the long and sinuous negotiation of his resignation from the bishopric of Cartagena. 
Key words: Cardinal Belluga; bishopric of Cartagena; reform of the Spanish clergy; renunciation of the bishopric.

Ante los muchos estudios que se han publicado sobre el cardenal Belluga, desde poco después de su muerte hasta la actualidad, habría que preguntarse qué se puede decir sobre este purpurado que ya no se haya dicho ${ }^{1}$. La verdad es que no mucho. No obstante, me atrevo a señalar que, mientras los estudios sobre su pontificado en Cartagena son numerosos y no se pueden aportar grandes novedades, no sucede lo mismo con lo referente a su actuación como cardenal de la Curia romana, sobre todo por lo que se refiere al conflicto de fidelidades que se le plantea cuando los intereses del rey no coinciden con los de la Santa Sede. Y la mejor manera de comprobarlo, como dice Irigoyen, es dejar que el propio protagonista hable y dar voz a los informes y cartas que envía desde Roma al rey y a sus ministros, así como a los juicios que emiten los embajadores de Felipe $\mathrm{V}$ sobre su comportamiento.

Sin embargo, el objetivo de las páginas que siguen es más modesto, pues solo pretenden analizar, básicamente a través de la correspondencia que mantiene con el ministro Grimaldo, su primera estancia en Roma (1721-1723), durante la que trabajó con denuedo para conseguir que el papa publicará una bula o breve para la reforma del clero español ${ }^{2}$, y la negociación de su renuncia al obispado para quedarse definitivamente en Roma.

\section{CARDENAl de la IGlesia ROMANA y VIAJE A ROMA PARA EL CÓNClaVE}

A principios de 1715 se habló de la creación de cardenales de corona y el candidato español parecía ser monseñor Molines por lo bien que había defendido los intereses del rey durante los seis años que llevaba de ministro de la embajada

1. Ante la inmensa bibliografía que existe sobre Belluga remito a la obra de VILAR, Juan Bautista. El cardenal Luis Belluga. Granada: Comares, 2001, que indica los estudios disponibles, a los que se pueden añadir los posteriores de MARTínez RIPOLL, Antonio. «Regalismo borbónico, reformismo eclesiástico y relaciones con Roma: el cardenal Belluga». En Alvar EZQUERRA, Alfredo; CONTRERAS, Jaime y Ruiz Rodríguez, José Ignacio (eds.). Política y cultura en la época moderna (cambios dinásticos, milenarismos, mesianismo y utopías). Alcalá de Henares: Universidad de Alcalá, 2004, pp. 29-50; IRIGOYEN LóPez, Antonio. Un obispo, una diócesis, un clero: Luis Belluga, prelado de Cartagena. Murcia: Academia de Alfonso X el Sabio, 2005; Luis Belluga y Moncada. La dignidad de la púrpura. Murcia: CajaMurcia, 2006, etc.

2. Vilar, María José. "La misión oficial del cardenal Belluga en Roma en 1722-1723, a través de un epistolario inédito". Hispania Sacra, 2010, 65/125, pp. 243-265, trata este tema, pero el artículo contiene algunas inexactitudes y se limita a examinar 16 copias de los despachos que Acquaviva escribe a Grimaldo (Archivo Histórico Nacional, en adelante AHN, Santa Sede, leg. 284) y hacen referencia al tema, sin tener en cuenta la correspondencia de Belluga con Grimaldo. De la misma autora también conviene ver "El Cardenal Belluga en Italia». En Luis Belluga y Moncada..., op. cit., pp. 317-329. 
en Roma ${ }^{3}$, pero en agosto se descartó su promoción "por estar en tan mal estado de salud que no tiene fuerza para aprovechar esta dignidad cuando se la dieren", y algunos comenzaron a hablar del obispo de Murcia, Luis Belluga, cuya conducta antirregalista era bien vista en Roma ${ }^{4}$. En el consistorio del 12 de julio de 1717 se concedió el capelo a Giulio Alberoni, a nómina de Felipe V, y dos años después al obispo Belluga por decisión pontificia, sin que interviniese el rey en su nombramiento.

Luis Belluga, obispo de Cartagena, fue creado cardenal en el consistorio del 29 de noviembre de 1719 por decisión de Clemente XI, pero rechazó el capelo, porque en 1706 se había comprometido por voto a no aceptar ninguna dignidad o encargo que le apartase de su obispado, cuyo ministerio le resultaba muy gravoso y tenía decidido presentar la renuncia, una vez que arreglase lo referente a las pías fundaciones que había establecido en la diócesis, según explica a Grimaldo dos años después:

Desde que entré en el obispado, lo que acepté con gran repugnancia y abracé por las instancias del cardenal Salazar, que era entonces mi prelado, mi ánimo ha siempre de no morir en el oficio de obispo, por ser para la debilidad de mis hombros una carga intolerable, que me trae siempre lleno de mil escrúpulos y fatigas, viendo lo mucho que siempre hay que remediar, las dificultades que se encuentran por las indisposiciones del tiempo en cualquier providencia de remedio que se toma, las pocas ayudas de acá y otras consideraciones, que todo esto concurre a hacérseme pesadísimo yugo en mi genio y conocimiento de mi obligación y deseo de cumplir con ella, e imposibilidades en la ejecución. Supuesta esta verdad, y que ha sido siempre muy frecuente en mí el decir que me muriera sino viviera con la esperanza de que no he de morir en el ejercicio de obispo, y que no esperaba otra cosa para renunciar a mi obispado absolutamente y retirarme a un monasterio a acabar mi vida en quietud, para asegurar con mayor certeza la eterna, que en dejar en erección mis fundaciones y celebrar mi sínodo (que hace 138 años que no se celebra en mi diócesis), que todo ello tenía regulado duraría hasta el año de 28, por lo que hasta dicho año hice la aplicación de tres partes de cuatro de los frutos de Cartagena para dichas fundaciones. Y tan seriamente esto y tan de veras, que tenía ya destinado y visto el monasterio, donde me había de retirar, que fue una de las razones, a más del voto, porque con tanta eficacia me resistía a la admisión del capelo, por parecerme que esta dignidad me había de impedir el logro de este mi deseo del retiro,

3. Auditor de la Rota romana por la Corona de Aragón desde 1685, apoyó a Felipe V y, al romperse las relaciones con Roma en 1709, fue nombrado ministro encargado de los negocios de la embajada hasta 1716, en que fue designado inquisidor general. Cf. BARRIO GOZALO, Maximiliano. "Monseñor Molines, ministro de Felipe V en Roma y conflicto de fidelidades (1709-1717)». Manuscrits. Revista d'Historia Moderna, 2017, 36, pp. 105-132.

4. Archivo General de Simancas (en adelante AGS), Estado, leg. 4766. Acquaviva a Grimaldo. Roma, 1 de enero y 6 de agosto de 1715 . 
como ha sucedido. De todo esto podrá inferir V. E. que mi ánimo no puede de ser otro que el mismo5.

Cuando llegó la negativa de Belluga a Roma, el cardenal Paolucci, secretario de Estado de la Santa Sede, pidió al cardenal Francesco Acquaviva, embajador de España en Roma ${ }^{6}$, que el rey le presionase para que aceptase el capelo, pero el embajador respondió "que no habiendo sido nombrado cardenal a nominación de S. M. el rey no quiere mezclarse en que acepte o deje de aceptar ${ }^{7}$. Ante esta respuesta, el papa Clemente XI envió un breve a Belluga, en el que alaba su virtud y pondera los méritos que le hacían merecedor de la púrpura, dispensándole de cualquier voto o juramento que hubiese hecho de no admitir dignidad, y mandándole aceptarla por obediencia, "porque no duda el papa que con la misma virtud que la rechazó, se ha de sujetar a obedecer sus preceptos» ${ }^{8}$. Ante el mandato pontificio se resignó y acepto el capelo.

Un año después, el 19 de marzo de 1721, falleció Clemente XI, y Acquaviva, al informar de su muerte, afirma que sería difícil conseguir que el Sacro Colegio retrasase la elección del nuevo papa hasta que llegasen los cardenales franceses y españoles, porque había deseo de hacerla con prontitud. En cambio, si el ministro del emperador quería detenerla, podía hacerlo con los votos de los cardenales vasallos que tenía en Italia. Además, si no llegaban los que estaban fuera, el partido hispano-francés no podía impedir que se eligiese a un candidato apoyado por los imperiales. Confiesa, no obstante, que no era fácil predecir en quién podía caer la tiara por la composición del colegio cardenalicio, pues no había más facción que las criaturas del último papa, que eran 44, aunque estaban desunidas y muchas no obedecían al cardenal Aníbal Albani, que era su cabeza. Apunta que el cardenal Paolucci era el que gozaba de mayor estimación, al que seguían Corsini y Cornaro, y concluye diciendo que también podía caer la elección en Conti, que tenía buenas prendas y, como había estado apartado de los negocios, no parecía que tuviera manifiestas exclusiones?

El 31 de marzo se inició el cónclave con cuatro partidos principales: las criaturas de Clemente XI mandadas por Aníbal Albani, los celantes, los imperiales y los

5. Ibid., leg. 4805. Belluga a Grimaldo. Roma, 18 de abril de 1722.

6. Barrio Gozalo, Maximiliano. "La Embajada de España en Roma principios del Setecientos. El cardenal Francesco Acquaviva y d'Aragona (1716-1725)". Roma Moderna e Contemporánea, 2007, XV, pp. 293-325; íd. La Embajada de España en Roma en la primera mitad del siglo XVIII. Madrid: Ministerio de Asuntos Exteriores, 2017, pp. 179-207.

7. AGS, Estado, leg. 4780. Acquaviva a Grimaldo. Roma, 20 de febrero de 1720, y Grimaldo a Acquaviva. Madrid, 1 de abril de 1720. Cf. CARDella. Lorenzo. Memorie storiche décardinali della Santa Romana Chiesa, VIII. Roma: Pagliarini, 1794, pp. 186-187, y VILAR, Juan Bautista. El Cardenal Belluga..., op. cit., pp. 277-279.

8. AGS, Estado, leg. 4781. Acquaviva a Grimaldo. Roma, 15 de marzo de 1720. El breve de Clemente XI a Belluga está fechado en Roma el 12 de marzo de 1720.

9. Ibíd., leg. 4788. Acquaviva a Grimaldo. Roma, 19 de marzo de 1721. 
borbónicos; pero, como los dos primeros estaban muy divididos, el predominio correspondía a los partidos de las coronas. Acquaviva caminó en sintonía con los franceses y, en los primeros días, Paolucci fue el más votado y estuvo a punto de ser elegido, pero el cardenal Althan declaró su exclusión por parte del emperador $^{10}$. Ante la imposibilidad de elegir a Paolucci, se iniciaron negociaciones y Albani, que tenía la facción más numerosa, propuso a cinco posibles candidatos: Pignateli, Corsini, Paracciani, Conti y Gozzadini. Los dos primeros dijeron que no querían ser propuestos; Paracciani tuvo que salir del cónclave y cayó su candidatura, y quedaron Conti y Gozzadini. Las criaturas de Clemente XI se inclinaron por Conti y Acquaviva confiesa que podía ser elegido, aunque tendría dificultades "por la afección que su casa había tenido siempre con el Imperio y por tener muchos parientes pobres». El 6 de mayo el agente de preces Félix Cornejo añade que el cónclave todavía duraría por los distintos pareceres de los cardenales y los partidos, porque, aunque el imperial era el más numeroso, no contaba con los sufragios suficientes; además se había desvanecido la elección de Conti, que se daba por cierta, y cobraba interés la candidatura de Pignatelli,

que entro anteayer con una aclamación extraordinaria del pueblo -dice Cornejo-, que le vaticinaba el pontificado, acordándose sin duda de su pariente Clemente XI que fue gran padre de los pobres, y me aseguran que este purpurado ha tenido 31 votos en los últimos escrutinios, y que Acquaviva había protestado contra esta elección, de cuya certidumbre estará V. E. informado, siendo voz común que Pignatelli es todo alemán y de una complacencia tan ciega por aquella nación que en su arzobispado de Nápoles, por no disgustarles, dejaba que violasen la inmunidad de las iglesias y que la gobernase a su fantasía ${ }^{11}$.

Acquaviva volvió a proponer al Sacro Colegio que, ya que se había aguardado a que llegasen los cardenales de otras naciones, sería justo esperar también la llegada de Borja y Belluga, pero no le respondieron y de nuevo prevaleció la candidatura de Conti, porque los cardenales franceses le ofrecieron su voto, confiando en su promesa de que nombraría un ministerio neutral, y poco después lo hicieron también los imperiales. El 8 de mayo de 1721 fue elegido el cardenal Conti, que tomó el nombre de Inocencio XIII y Acquaviva lo describe con estas palabras:

Todos han saludado con gran aplauso y con gran alegría que haya sucedido en la cátedra de Pedro un hombre sólido, de estirpe aristocrática, de la nobleza romana, un hombre del que nosotros esperamos la plena satisfacción de todos los príncipes por su gran justicia y por su vasta inteligencia, capaz de hacer frente, en gran medida, a las tareas del gobierno ${ }^{12}$.

10. Ibíd. Ascanio a Grimaldo. Roma, 6 de abril de 1721.

11. Ibíd., leg. 4793. Cornejo a Grimaldo. Roma, 6 de mayo de 1721.

12. Ibid., leg. 4789. Acquaviva a Grimaldo. Roma, 9 de mayo de 1721; AHN, Santa Sede, leg. 283, exp. 1. Cónclave y elección de Inocencio XIII; y PASTOR, Ludwid von. Historia de los papas en la época de la Monarquía absoluta, XXXIV. Barcelona: Gustavo Gili, 1937, pp. 1-22. 
Los cardenales Belluga y Borja se pusieron en camino para asistir al cónclave, pero cuando llegaron a Roma, el 30 de mayo, ya hacía veintidós días que había sido elegido el nuevo papa. Salieron a recibirlos el cardenal Acquaviva, los dos auditores de la Rota y el agente de preces, y también enviaron sus mutas los cardenales Rohan y Gualtieri y el príncipe de Palestrina. Cargaron su equipaje y se dirigieron al palacio de la Embajada, donde Acquaviva había preparado hospedaje para ellos y sus acompañantes. Belluga manifestó deseos de ir a un convento de camaldulenses, donde tenía reservado un apartamento por disposición del cardenal Zondadari, pero Acquaviva le convenció para que se quedase en el palacio hasta que se celebrase la función de recibir el capelo, que sería dentro de ocho días, para dar tiempo a que completaran sus equipajes todos los cardenales que debían tomar el capelo, "que son los dos nuestros, dos de Francia, dos de Portugal y otros más, siendo el decano o más antiguo de estos purpurados Rohan, y como a tal le toca en nombre de todos el hacer una breve arenga a S. S.». Debían ir a caballo, haciendo una gran cabalgata desde la puerta del Popolo hasta el palacio de Montecaballo (Quirinal), donde se tendría el consistorio público. Unos días después, el papa recibió en audiencia a Borja y Belluga, y después Belluga se fue a vivir con los camaldulenses, sin querer esperar en el palacio a la función del capelo, que se celebró el día 10 por la mañana, con el acompañamiento de muchos cardenales, caballeros romanos, prelados y numeroso séquito ${ }^{13}$, y que Belluga describe con estas palabras:

Hemos recibido hoy el capelo, que ha sido una función dilatadísima de ocho horas, desde las siete a las tres de la tarde, y como a este precedió haber besado el pie de SS de secreto por la escalerilla el viernes de la semana pasada, quien hizo grandes expresiones de su cordialidad a S. M. y la Corona con gran ternura, durando más de media hora la audiencia ${ }^{14}$.

Belluga, que había manifestado públicamente su impaciencia por volver a su diócesis, sorprendió a todos al manifestar que había tomado la decisión de pasar el invierno en Roma para despachar algunos negocios de su iglesia. Acquaviva quedó sorprendido por esta resolución, pues por muchos que fueran los negocios no le llevaría más de un mes en resolverlos y supuso que habría otros motivos secretos que el rey no debía ignorar ${ }^{15}$. Y claro que había otros motivos, porque Belluga había dicho al padre Daubenton, confesor del rey, que le agradaba la idea que le habían propuesto algunos cardenales de quedarse en Roma de forma definitiva, bien renunciando el obispado o dándolo en coadjutoría, siempre que el rey lo aceptase y le asignase la congrua necesaria para mantenerse en la Corte romana. Pero, poco después, al conocer un poco más al cardenal Acquaviva,

13. AGS, Estado, leg. 4793. Cornejo a Grimaldo. Roma, 3 y 10 de junio de 1721.

14. Ibid., leg. 4795. Belluga a Grimaldo. Roma, 10 de junio de 1721.

15. Ibíd., leg. 4790. Acquaviva a Grimaldo. Roma, 16 de agosto de 1721 . 
cambió de opinión y llegó a la conclusión de que no convenía a la quietud de su conciencia, ni a su forma de ser, estar en Roma con este purpurado ${ }^{16}$.

Esta afirmación de Belluga está en relación con los desencuentros que tuvo con Acquaviva desde el primer momento por no atenerse a las disposiciones reales de no visitar a los cardenales del partido imperial y, en concreto, a Francesco del Giudice ${ }^{17}$. A pesar de ello Belluga visitó al purpurado y lo justificó ante el embajador diciendo que siendo la primera visita que hacía al Sacro Colegio no se debía considerar comprendida en la orden general de no tratarle. Acquaviva le respondió que él no interpretaba las órdenes del rey sino que las ejecutaba, pues cuando el monarca quería hacer alguna distinción lo declaraba, "como en carta de 11 de noviembre de 1720 me dijo que, en cuanto al cardenal Cienfuegos, le podía tratar en actos de comunidad, excusando cualquier otra concurrencia ${ }^{18}$.

Cuando el cardenal Borja fue a despedirse del papa, le comentó su extrañeza por no haber visitado a Giudice como había hecho Belluga, pero Borja respondió que no sabía las razones de Belluga, "pero sí sabía que el rey le había dicho antes de partir que se abstuviese de visitarlo». Como respuesta el cardenal Althann, embajador imperial, prohibió a los cardenales dependientes del imperio tratar con Acquaviva y con Borja, pero no con Belluga, y comenta Acquaviva que no había querido dar ninguna respuesta, porque como Borja estaba para partir a España, "quedo yo solo expuesto a las iras y al castigo que los alemanes quieren darme, sin que esto me cause la menor pena, y si el rey quiere que haga una protesta estaré esperando su orden ${ }^{19}$.

\section{LA REFORMA DEL CLERO Y LA BULA APOSTOLICI MINISTERII}

Los decretos tridentinos establecían unos requisitos mínimos para acceder a la clerecía que las constituciones sinodales de cada obispado ratifican y completan. Los requisitos culturales exigidos, además de imprecisos, eran poco exigentes,

16. Ibid., leg. 4799. Belluga a Daubenton. Roma, 19 de octubre de 1721.

17. Este cardenal napolitano había estado dos veces encargado de los negocios de la Embajada española en Roma durante los últimos años de Carlos II, y sirvió a Felipe V con fidelidad, que le nombró inquisidor general en 1712, y durante el año 1715 y primera mitad de 1716 se convirtió en el personaje más influyente de la política española, hasta que en julio de 1716 fue desplazado por Alberoni y volvió a Italia. El rey, a instancias de Alberoni, le acusó de traidor y prohibió a los súbditos españoles relacionarse con él, motivo por el cual Giudice se pasó al partido imperial. Cf. BARRIO Gozalo. Maximiliano. "El Cardenal Francesco del Giudice y el gobierno de la Monarquía, entre los Austrias y los Borbones». Cheiron, 2010, 53-54, pp. 327-366.

18. AGS, Estado, leg. 4791. Acquaviva a Grimaldo. Roma, 20 de septiembre de 1721.

19. Ibidem. 
lo que propició que el nivel cultural de la mayor parte del clero parroquial, es decir, los beneficiados y capellanes, fuera muy elemental ${ }^{20}$.

La guerra de Sucesión a la Monarquía española repercutió negativamente en la vida del clero y, a finales de 1713, el fiscal del Consejo de Castilla, Melchor de Macanaz, al ver que no se cumplían las disposiciones que el concilio de Trento exigía para acceder a las órdenes sagradas, propuso a los obispos la creación de colegios en los que se formasen los aspirantes a las órdenes sagradas, a fin de mejorar su formación cultural y asegurar una congrua suficiente ${ }^{21}$. La mayoría de los obispos no compartía la propuesta del fiscal y respondió que se exigía a cada uno de acuerdo con la calidad del beneficio eclesiástico que disfrutaba. En cambio, a Belluga, obispo de Cartagena, le parecía muy útil para eliminar la ignorancia y la relajación que experimentaba el clero en la mayoría de las diócesis ${ }^{22}$.

En 1715 Felipe V solicitó el dictamen de los obispos para llevar a cabo la reforma moral de la sociedad y del clero. Por lo que respecta al clero secular, la mayoría de los prelados reconoce la necesidad de su reforma para evitar los comportamientos escandalosos que se daban en muchos casos. Sin embargo, no hay coincidencia al identificar cuáles eran esos "procederes escandalosos". El de Jaén habla de la falta de moderación del estado eclesiástico, de su secularización, inmodestia y falta de ejemplaridad. El de Astorga critica la inmoralidad y el concubinato de los clérigos. Al de Ávila le preocupa el traje de abate que habían comenzado a utilizar algunos clérigos, al que califica de indigno y escandaloso; etc. Pero es el obispo de Cartagena quien más incide en la falta de disciplina de algunos eclesiásticos y en el incumplimiento de sus obligaciones pastorales, hecho que se observaba de forma especial en las vicarías de las órdenes militares ${ }^{23}$.

20. Este tema ha sido tratado, con más o menos amplitud, por la mayor parte de los estudios sobre el bajo clero, por lo que me limito a indicar tres obras: CANDAU CHACHón, María Luisa. La Carrera Eclesiástica en el siglo XVIII. Sevilla: Universidad de Sevilla, 1993, pp. 207-383; MORGADO GarCía, Arturo. Ser clérigo en la España del Antiguo Régimen. Cádiz: Universidad de Cádiz, 2000, pp. 49-57; y Barrio Gozalo, Maximiliano. El Clero en la España Moderna. Córdoba: CSIC-CajaSur, 2010, pp. $142-154$.

21. AHN, Consejos, leg. 7294. Informe del Fiscal General del Consejo a los Obispos sobre la fundación de colegios-seminarios en estos reinos. Madrid, 29 de noviembre de 1713. Este informe y las respuestas de los obispos han sido analizadas por BARrio GOZALO, Maximiliano. «El clero bajo sospecha a principios del siglo XVIII. El informe de Macanaz y la respuesta de los obispos». Investigaciones Históricas, 2002, 22, pp. 47-62, al que me remito.

22. AHN, Consejos, leg. 7294. Belluga al Consejo. Alcalá del Río, 16 de enero de 1714

23. Los dictámenes de los prelados se encuentran en el AGS, Patronato Eclesiástico, leg. 338, y han sido analizados por MARCos MARTín, Alberto. "Una mirada clerical a la España de comienzos del siglo XVIII. Los dictámenes de los obispos de 1715”. En BERnardo Ares, José Manuel de, y MuÑoz MACHADO, Santiago (dirs.). El Estado-Nación en dos encrucijadas bistóricas. Madrid: Iustel, 2006, pp. 75-135 (lo referente a la reforma del clero en las pp. 98-101). RODRíGuEz POMAR, F. «Una página de política española. Dictámenes de los prelados en 1715", Razón y Fe, 1941, 122, pp. 334-344; y 1942, 122 , pp. 49-66, publicó algunos fragmentos sueltos de los dictámenes; y posteriormente se han trascrito y publicado los dictámenes de los obispos de Segorbe y Cartagena por Benito Durán, Ángel. «Don Diego 
Sin embargo, a la hora de proponer remedios no ofrecen grandes novedades $y$, en general, se inclinan por castigar con severidad los pecados públicos que cometen los eclesiásticos, porque, según Belluga, algunos obispos los pasan por alto o tienen la manga muy ancha a la hora de castigarlos "por no entrarse en ruidosos pleitos ${ }^{24}$. No obstante, todos convienen en que la solución a la relajación de los clérigos se encontraba en promover la disciplina eclesiástica y extremar los cuidados para no admitir a las órdenes a quienes no tuvieran una clara inclinación al estado eclesiástico. Y el de Tortosa, Miguélez de Mendaña, pide al rey que encargue a los prelados que no confieran órdenes menores si no era conforme a lo dispuesto por el concilio de Trento ${ }^{25}$.

En cuanto al clero regular, Belluga señala que había mucho que remediar, «así en los púlpitos, por la doctrina que predican, que por lo general no es hoy la que conviene para la reforma cristiana, como en los confesionarios, que por las anchuras que en ellos se practican, las conciencias no se curan ${ }^{26}$. Las monjas también necesitaban remedio, porque la pobreza de algunos conventos las impedía hacer vida en común de acuerdo con lo que mandaban las constituciones. Por ello sugiere que los superiores no concedan licencia para nuevas profesiones, a fin de que en cada convento no haya más religiosas que las que puedan mantenerse con las rentas fijas y las limosnas que reciben, según disponía el concilio de Trento.

Por último, como posible remedio para llevar a cabo la reforma del clero se apunta la necesidad de celebrar sínodos diocesanos y concilios provinciales, como había propuesto el obispo de Guadix y apoyó Belluga. Porque, aunque el concilio de Trento mandaba celebrarlos anualmente en la diócesis y cada tres años en la provincia eclesiástica, la realidad era muy distinta, ya que en alguna diócesis hacía más de un siglo que no se celebraban sínodos, y en Murcia hacía ciento treinta y ocho años. En cuanto a los concilios provinciales, señala Belluga que en la archidiócesis toledana no se celebraban desde 1582, y juzga tan importante este medio que pide al rey, si fuera preciso, la celebración de concilios nacionales ${ }^{27}$.

El concordato de 1717 no solucionó los problemas de reforma que propugnaban los regalistas, y la ambición de Alberoni se encargó de evidenciar su carácter provisional, rompiendo las relaciones con Roma al año siguiente ${ }^{28}$. Una vez que se

Muñoz y Vaquerizo, obispo de Segorbe, consejero de Felipe V». Boletín de la Sociedad Castellonense de Cultura, 1985, 61, pp. 19-31; y "Don Luis Belluga y Moncada, cardenal de la Santa Iglesia y obispo de Cartagena, consejero de Felipe V». En Cremades Guiñán, Carmen María (ed.). Estudios sobre el cardenal Belluga. Murcia: Academia Alfonso X el Sabio, 1985, pp. 137-210.

24. AGS, Patronato Eclesiástico, leg. 338. Belluga a Grimaldo. Murcia, 16 de abril de 1715.

25. Ibíd. Miguélez de Mendaña a Grimaldo. Tortosa, 29 de abril de 1715.

26. Ibid. Belluga a Grimaldo. Murcia, 16 de abril de 1715.

27. Ibidem.

28. EGIDO LóPEZ, Teófanes. "El regalismo y las relaciones Iglesia-Estado en el siglo XVIII». En Historia de la Iglesia en España, IV. Madrid: BAC, 1979, pp. 169-172; FERNÁNDEZ ALONSO, Justo. "Un periodo de las relaciones entre Felipe V y la Santa Sede (1709-1717)». Anthologica Annua, 1955, 3, pp. 9-88. 
restablecieron las relaciones en 1720, el gobierno se propuso llevar a la práctica los viejos proyectos reformistas, relegados en el concordato de 1717 a una acción posterior. Felipe V mostró interés por la reforma del clero, pero quería controlarla de alguna manera y, ante el parecer del arzobispo de Toledo, Valero Losa, de la conveniencia de hacerlo por medio de concilios provinciales y sínodos diocesanos, de acuerdo con las disposiciones de los sagrados cánones y del concilio de Trento, el 30 de enero de 1721 recomendó a los obispos su pronta celebración para llevar a cabo la reforma bajo su real protección ${ }^{29}$.

Sin embargo, cuando Belluga fue a Roma para asistir al cónclave de 1721, en el que fue elegido papa Inocencio XIII, vio que la Curia romana no era partidaria de que se hiciera la reforma por medio de concilios provinciales. Porque, aunque no lo podía impedir, "porque sería un escándalo grande para toda la Iglesia impedir lo que mandan los sagrados cánones y concilios con todo rigor ‘30 ante los problemas que había en Francia con los jansenistas que rechazaban la bula Unigenitus (1713) y habían apelado al futuro concilio ${ }^{31}$, le aconsejaron llevar a cabo la reforma de la disciplina eclesiástica por medio de un breve o bula pontificia, y el cardenal Corradini le pidió que hiciera un escrito con los principales puntos que había que reformar. Belluga se pasó el verano redactando el escrito sobre los puntos de reforma de la disciplina eclesiástica, el buen gobierno de las diócesis, el cumplimiento de las disposiciones tridentinas y la reforma del clero,

principalmente de la multiplicidad de eclesiásticos inútiles, sobre todo tonsurados, y modo que se deba en adelante practicar, así para que todos los eclesiásticos sean útiles a las iglesias y al reino, y menos el número que defraude sus tributos, como también para que el crecido número que hoy hay de los de menores inútiles se pueda reducir a la debida moderación. Y las muchas capellanías que hay en las iglesias, que apenas tienen más que el título y solo sirven para multiplicar los clérigos, sin servir las iglesias ni ser de provecho a los pueblos, defraudan a S. M. los tributos y deben suprimirse o unir entre ${ }^{31^{32}}$.

29. Real cédula de Felipe V, 21 de enero de 1721. Una copia en FuENTE, Vicente de la. Historia eclesiástica de España, VI. Madrid: Impresores del Reino, 1875, pp. 320-323.

30. AGS, Estado, leg. 4799. Belluga a Daubenton. Roma, 19 de octubre de 1721. El padre Daubenton fue confesor de Felipe V entre 1700-1705 y 1715-1723, en que murió, y después de la caída de Alberoni ejerció mucha influencia sobre el rey. $C f$. CRIADO DEL VAL, Manuel. «El itinerario político del Padre Daubenton en la Corte de Felipe V». En Caminería Hispánica. Actas del VII Congreso Internacional Francia-España. Madrid: Casa Velázquez, 2004, pp. 1-24; y DESOS, Catherine. Le vie du R. P. Guillaume Daubenton (1648-1723). Un jésuite français à la cour d'Espagne et Rome. Córdoba: Universidad de Córdoba, 2005.

31. Molina, Diego M. "La discusión en torno a la bula de Unigenitus". Archivo Teológico Granadino, 2009, 72, pp. 31-57; CARREYRE, J. "Unigenitus (bulle)». En Dictionaire de théologhie catholique, XV, pp. 2061-2162.

32. AGS, Estado, leg. 4799. Belluga a Daubenton. Roma, 19 de octubre de 1721. 
Y concluye diciendo al padre Daubenton que convenía que el monarca escribiese al papa para que apoyase la reforma del clero, mientras que él se lo diría al cardenal Corradini para que indicase a Inocencio XIII los puntos que convenía reformar $^{33}$. Al mismo tiempo pidió al monarca que ordenase al cardenal Acquaviva, embajador de España en Roma, que le ayudase para sacar adelante la reforma ${ }^{34}$. El papa nombró una congregación particular, formada los cardenales Gualteri, Pico della Mirandola, Zondadari, Belluga, Salerno y Origo, y monseñor Lambertini como secretario, para estudiar la propuesta de Belluga, que se atenía al puntual cumplimiento del concilio de Trento y trataba de la formación del clero, los ordenandos y los párrocos, los regulares y la observancia de los decretos tridentinos. Belluga, aunque reconoce la lentitud con que los curiales romanos tramitaban los negocios pendientes, pecaba de ingenuo al pensar que a finales de diciembre podía estar despachado el documento sobre la reforma del clero, "que es lo único que aquí me detiene ${ }^{35}$. Pero la Curia impuso sus tiempos y el purpurado tuvo que esperar casi dos años para volver a España con el breve sobre la reforma del clero.

La Congregación celebró la primera sesión, pero como el proyecto de Belluga era voluminoso y muchos los temas que había que analizar, se adoptó el método de organizar los contenidos por temas o dubios para que los purpurados emitieran su respuesta ${ }^{36}$. De los primeros capítulos sobre el clero secular, se examinaron diez dubios y seis se resolvieron a gusto de Belluga,

pues quiere el puntual cumplimiento del concilio de Trento y aquí también se quiere lo mismo, sin embargo son todas las resoluciones más alabando el celo de Belluga por sus deseos de reforma y exhortando a los demás a obispos a imitarle más que a mandarlo formalmente, como Belluga pedía, y parece en fin que casi todas las materias han de tener la misma resolución ${ }^{37}$.

Belluga envió los puntos resueltos al arzobispo de Toledo y confiesa a Grimaldo que el tema iba para largo, porque la segunda congregación no podía tenerse hasta pasadas las carnes tolendas (días de carnaval) y, durante la cuaresma, se podrían tener muy pocas por los compromisos pastorales de los cardenales. Le recuerda la conveniencia de que el rey escriba al papa, recomendando la importancia del negocio de la reforma y pide ayuda económica para mantenerse en Roma el tiempo que dure la resolución de todos los temas, porque si abandonaba

33. Biblioteca de la Embajada de España ante la Santa Sede (en adelante BEESS), ms. 73, ff. 10-77. Libellus qui Innocentio XIII exponitur á Cardinali Belluga super aliquibus ad disciplinam attinentibus... Romae, 1721 (firmado por Belluga el 3 de diciembre de 1721).

34. AGS, Estado, leg. 4799. Belluga a Daubenton. Roma, 19 de octubre de 1721. Ver el artículo de Vilar, María José. "El cardenal Belluga en Roma en 1722-1723...", art. cit., pp. 248-250.

35. AGS, Estado, leg. 4799. Belluga a Grimaldo. Roma, 25 de octubre de 1721.

36. BEESS, ms, 18, ff, 36-136. Elenco de dubii da proporsi sopra il discurso del Sr. Cardinale Belluga disteso da Mons. Lambertini, segretario della Congregazione deputata da S.S. li 30 de dicembre de 1721 .

37. AGS, Estado, leg. 4799. Acquaviva a Grimaldo. Roma, 31 de enero de 1722. 
la negociación se perdería el dinero gastado, el trabajo realizado y lo que ya había aprobado la congregación. Por ello, recalca la necesidad de permanecer en Roma, ya que sin su presencia y sus representaciones no se resolverían las cosas como convenía ${ }^{38}$.

A mediados de febrero, Acquaviva recibió la carta del rey para el papa, pidiéndole que atendiera las instancias de Belluga sobre los diferentes puntos de reforma que proponía. Pero Acquaviva comunicó a Grimaldo que había oído a uno de los miembros de la congregación que todo lo que pedía Belluga era muy justo y muy santo, "pero con tanto rigor a la letra del Concilio, que es más para desearse que para mandarse, y más para alabar a los que lo cumplen que para reprender los que no llegan a conseguirlo». Además, había criticado tanto la poca doctrina del clero secular y los inconvenientes que había en los regulares que los miembros de la congregación se habían formado un mal concepto de la nación, "pero todo esto se debe al gran celo de Belluga, tan enamorado de lo más perfecto» ${ }^{39}$.

Acquaviva informó a Belluga de la llegada de la carta que el rey había escrito al papa sobre la reforma del clero, junto con el despacho de Grimaldo del 16 de enero, y decidieron entregarla al cardenal secretario para que la pasase al papa, a fin de que interpusiera su autoridad en el pronto despacho de la reforma del clero $^{40}$, junto con un papel para recalcar la importancia de la reforma.

Deseando el rey -dice el papel-, como un bien importante a la iglesia, la reforma del clero secular y regular de sus reinos, y la disciplina, moderación y remedio de los desórdenes y perjuicios que de ellos resultan, y al mismo del estado eclesiástico por la multitud de ordenados, principalmente de tonsura y menores órdenes, sin ninguna necesidad ni servicio de las iglesias, y las más de las veces a título de capellanías fantásticas de muy moderada o ninguna congrua; porque reconoce S. M. que estos y otros desordenes y perjuicios que se padecen y experimentan en los juicios y en las curias eclesiásticas, por el abuso de las inhibiciones de los jueces superiores en curia y extra curia con lo que se reglan las partes y se les hacen notables agravios en sus derechos y expensas haciendo eternos los pleitos ${ }^{41}$.

Belluga dio las gracias al rey por la carta que había escrito al papa y por pedir a Acquaviva que le ayudase en las providencias que el papa debía tomar para la reforma de la disciplina eclesiástica. Un mes después, informó que en las dos congregaciones que habían celebrado se habían acordado todos los puntos a su satisfacción y el lunes santo tendrían la tercera reunión. Pero se lamenta por la multitud de españoles que llegaban a Roma, porque, «además de venir mal vestidos y sin dinero, van a comer la sopa de los conventos o la que él da a los

38. Ibíd., leg. 4800. Belluga a Grimaldo. Roma, 3 de febrero de 1722.

39. Ibid., leg. 4799. Acquaviva a Grimaldo. Roma, 14 de febrero de 1722 .

40. Ibid., leg. 4800. Acquaviva a Grimaldo. Roma, 21 de febrero de 1722.

41. Ibid., leg. 4805. Papel que deberá acompañar a la carta del rey al papa a favor de la reforma eclesiástica, s. f. 
pobres dispensantes, que en los primeros días de cuaresma llegaron a setenta y

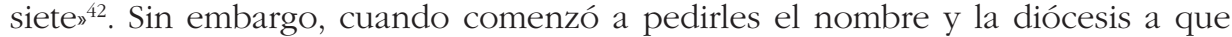
pertenecían, la mayoría no volvió y solo continuaron asistiendo dos docenas. Ante un espectáculo tan vergonzoso e indecoroso para la nación, pide que se tomen medidas radicales, porque la mayoría llegaba sin dimisorias o testimoniales de sus prelados y no hacían nada útil a la iglesia y a la sociedad, al igual que muchos que las llevaban. Por eso, pide al rey que escriba a los prelados para que no den dimisorias a ninguno que sus padres o parientes no le aseguren cien pesos al año y vestido decente, y haya estudiado alguna facultad, ordenando al cardenal Acquaviva que, al que llegase sin dimisorias o no viviese con decencia, lo hiciese volver a España, y lo mismo a todos los que, con dimisorias o sin ellas, desacreditaban a la nación, ya que muchos decían que eran caballeros y se convertían en la irrisión de los curiales. Y termina diciendo que, con las providencias que se estaban tomando sobre los requisitos para ordenarse de prima tonsura, se remediará mucho el problema y evitará que vengan los inútiles y la escoria de la nación. Pero, como esta medida reducirá sensiblemente el número de los pretendientes que iban a Roma y esto podía molestar a los curiales, pide que se suspenda hasta que se expida la bula, "de forma que este mal que se ha padecido tantos años se tolere estos meses más» ${ }^{43}$.

La Congregación aprobó los temas referentes al clero secular sin apenas discusión, pero cuando se empezó a tratar de los regulares la negociación se complicó por la oposición de los procuradores generales de las órdenes religiosas. La situación se enrareció tanto que el papa manifestó deseos de que Belluga se fuera de Roma cuanto antes, ante el temor de que alborotase al clero de España con el proyecto que había presentado para corregir sus abusos y prevenir su ignorancia,

cuyo escrito oigo decir -informa el agente de preces Cornejo- que en lo general tiene poca aprobación, y todas las resoluciones que hasta ahora se van tomando tocante a los dubios que deduce son de que se recurra al Concilio y a los cánones, en donde todo está prevenido, sin necesitarse de más que de apremios a su cumplimiento a los que contravinieren a sus decisiones ${ }^{44}$.

El cardenal Belluga no se dio por enterado de estos rumores y, a pesar de la lentitud con se avanzaba, continuó con la negociación. Informó al arzobispo de

42. Ibid., leg. 4805. Belluga a Grimaldo. Roma, 21 de febrero y 21 de marzo de 1722 .

43. Ibidem.

44. Ibid., leg., 4796. Cornejo a Grimaldo. Roma, 14 de marzo de 1722. Además, indica que Belluga "está haciendo traducir al latín, sin que se sepa con qué intento, el papel que en esa Corte se le desaprobó tocante al precio de la sal». Es decir, el Memorial que da a S. M. el obispo de Cartagena, don Luis Belluga, sobre los acrecimientos e impuestos de la sal. En que representa a S. M. los motivos que tiene para proceder contra el administrador general de las salinas de este reino por lo perjudicado que en dichos acrecimientos se halla el clero secular y regular de su diócesis en su inmunidad y libertad que debe gozar de todos tributos, cargas, impuestos y exacciones... Murcia, 29 de noviembre de 1713. 
Toledo del contenido de las cinco congregaciones que habían tenido, «todas conforme a mi papel", y le dice que ya solo quedaba otra sobre el tema de los regulares, aunque los provinciales generales habían entregado a monseñor Lambertini ${ }^{45}$, secretario de la Congregación del Concilio y de la Congregación particular, un memorial pidiendo que se dejasen las cosas como estaban. Belluga confiaba que la Congregación no tuviera en cuenta el memorial de los provinciales y acordase lo que disponía el Concilio y las bulas pontificias, tanto en orden a no admitir más religiosos que los que pudiera mantener cada convento, como los demás puntos de su propuesta. Además, si los provinciales tenían algo que representar debían decírselo a él, sabiendo que el rey estaba muy interesado en la reforma. "Y digo esto porque será posible que luego que salga la bula los religiosos acudan a $\mathrm{S}$. M. y empiecen a hacer tanto ruido que se haga en mucha parte inútil el remedio", a pesar de lo mucho que se ha trabajado y las disposiciones que se han tomado gracias a las aportaciones de Lambertini ${ }^{46}$.

El día 30 de julio se celebró la sexta y última congregación, en la que se concluyó la discusión del tema sobre los regulares, acordando que debía cumplirse lo dispuesto por el Concilio en orden a que los conventos no tuvieran más religiosos que los que podían mantener con las rentas y limosnas, y que el papa daría facultades al nuncio pontificio para ejecutarlo. A juicio de Belluga, aunque a primera vista su ejecución parecía difícil, no lo era tanto, si el nuncio mandaba a los subcolectores de cada diócesis o a los obispos que ordenasen a los superiores religiosos presentar las cuentas de los ingresos de los conventos durante el último quinquenio, tanto los provenientes de rentas como de limosnas, para saber los ingresos anuales que tenía cada convento. Y, sumando el importe de los conventos de cada provincia, se podía regular el número de religiosos que podía mantenerse con ese dinero, de tal manera que si excedía a la capacidad de los ingresos se tomarían medidas para reducirlo, limitando las profesiones, que es lo que se había hecho en Italia y era el medio más eficaz para reducir el número de religiosos.

Y en esta conformidad, ejecutada esta diligencia, así de los conventos de religiosos como de monjas, y señalado por el nuncio el número que cada convento puede mantener, precediendo consulta a los obispos de cuanto necesita en su territorio un religioso de tal o tal orden, o una religiosa, para la manutención de todo lo necesario, según lo barato o caro del país, entonces se pide bula a S. S. confirmando el número de cada convento y de los que cada año se pueden admitir en la provincia con pena de nulidad de profesión, y S. S. no la negará como para Italia se han dado otras muchas. Y esto conviene que se haga con el mayor secreto y conviene que la facultad a los obispos sea delegada para que puedan delegar en sus vicarios y curas

45. Prospero Lambertini fue creado cardenal in pectore en 1726, pero no fue proclamado hasta el 30 de abril de 1828. Fue elegido papa el 17 de agosto de 1740 y tomó el nombre de Benedicto XIV. Cf. Rosa, Mario. "Benedetto XIV». En Enciclopedia dei Papi, III. Roma: Istituto della Enciclopedia Italiana, 2000, pp. 446-461.

46. AGS, Estado, leg. 4805. Belluga a Grimaldo. Roma, 30 de mayo de 1722. 
para que reconozcan los libros con un notario, por lo que en un mismo tiempo se puede hacer esta diligencia en toda España ${ }^{47}$.

Unos días después, Acquaviva comunicó a Grimaldo que la reforma eclesiástica del clero se había discutido largamente en una Congregación particular, y sus miembros habían resuelto todos los temas a satisfacción de Belluga. Por tanto, de acuerdo con la orden del rey y la solicitud de Belluga, había pedido al papa que aprobase las resoluciones y las mandase guardar con una constitución o un breve apostólico. El papa se mostró dispuesto a hacerlo, pero como el secretario de la Congregación todavía no había presentado la relación de lo que se había determinado, esperaba hacerlo cuanto antes para complacer al rey, que tanto deseaba la reforma de los eclesiásticos de sus reinos ${ }^{48}$.

Sin embargo las protestas de las órdenes religiosas de España complicaron la situación, porque los diputados del general de los carmelitas y de los mercedarios, en nombre de las demás religiones, pidieron al papa que escuchase sus razones antes de promulgar una constitución o breve sobre las proposiciones de Belluga. Porque, aunque no eran novedades sino cosas determinadas por el concilio de Trento y otras leyes apostólicas, algunas atentaban contra sus privilegios y costumbres, y sería muy difícil cambiarlo, tratándose solo de cuestiones de disciplina y no tener mayor importancia para la Iglesia ${ }^{49}$.

Monseñor Lambertini, secretario de la Congregación, que por invitación del papa había redactado la minuta de la bula sobre la reforma del clero de España, pasó el texto a Belluga para que lo revisase y viese si había que añadir o quitar algo. Belluga lo completó con algunos detalles para mayor claridad y quedó satisfecho con el texto, porque incluía todo lo que el rey había pedido a los obispos y al papa. Sin embargo, el cardenal Spinola, secretario de Estado de la Santa Sede, que protegía a los procuradores generales de los religiosos, creía necesario escucharlos antes de que el papa firmase un documento que alteraba las costumbres de los regulares. Belluga pidió ayuda a Acquaviva para que mostrase su malestar por la sugerencia de Spinola y dijese al papa que el rey sentiría mucho que se retrasase la expedición de la bula, ya que habría que celebrar otra Congregación para responder a las alegaciones de los religiosos, y esta no se podía tener hasta mediados de noviembre porque la mayoría de los cardenales se habían ido a sus casas de campo. Pero Spinola insistió en que había que oírlos antes o después de expedir la bula, y convenía hacerlo antes para que luego no se opusieran a su ejecución. Belluga no entendía la postura del cardenal secretario en defensa de los religiosos, pero tuvo que conformarse, y juzgó la detención de la expedición de

47. Ibíd. Belluga a Grimaldo. Roma, 1 de agosto de 1722. Respecto al dubio de las capellanías, como la Congregación no había dado respuesta, Belluga insiste en que se resuelva lo mismo que proponía en su memorial, es decir, la unión de unas a otras para formar una que sea congrua.

48. Ibid., leg. 4801. Acquaviva a Grimaldo. Roma, 8 de agosto de 1722.

49. Ibid., leg. 4803. Acquaviva a Grimaldo. Roma, 12 de septiembre de 1722. 
la bula como un insulto al rey, a la Santa Sede y a la Congregación de cardenales que había aprobado los puntos que contradecían los religiosos y eran copia literal de las disposiciones tridentinas ${ }^{50}$.

Ante el compás de espera, Belluga agradeció los dos mil doblones que le habían mandado para el viaje de vuelta, y añade que era increíble lo que se gastaba en Roma, porque no tenía corazón para dejar de socorrer a los pobres españoles que le pedían ayuda y hacer las limosnas indispensables, "porque en Roma había más pobres que en todo el mundo y era escandaloso no socorrerlos, de forma que si en España las limosnas anuales no llegaban a dos mil escudos aquí eran necesarios cuatro mils ${ }^{51}$.

Al recibir la carta del 16 de septiembre, en que Grimaldo le comunicaba que el rey no aceptaba su renuncia al obispado en la forma que la había presentado, respondió que estaba resuelto a salir de Roma el cuatro o el cinco de enero en dirección a Livorno o Génova, donde embarcaría, «aunque arriesgue mi vida, pues aunque deseaba hacer el viaje por tierra y más pudiendo yo penetrar por Francia, no teniendo con que poderlo hacer, es preciso elegir este medio». Estaba convencido de que podría llevar la bula consigo, porque, a pesar de que los procuradores religiosos pretendían enredar el negocio y detener la expedición de la bula con sus representaciones, había resuelto con el parecer de sus compañeros de la Congregación que los cinco dubios que se referían a los religiosos se separasen del texto para que los religiosos tuvieran tiempo de decir lo que quisieran al papa, que era el defensor de los sagrados cánones y disposiciones del Concilio, a fin de que resolviese lo que juzgase conveniente y lo publicase en un documento separado, y así no se retrasase la expedición de la bula sobre la reforma del clero secular. Para concretar estos puntos y resolver algunas dudas planteadas por el arzobispo de Toledo se iban a reunir los miembros de la Congregación, a fin de aprobar el nuevo texto de la bula y entregarlo al papa para que lo firmase, con la cláusula de que por otra bula tomaría las providencias necesarias sobre el estado regular, "aunque la principal contradicción es sobre el punto de lo establecido por Trento y reiterado por seis romanos pontífices, desde Pío V, de que no se admitan más religiosos y religiosas que las que se puedan mantener con las rentas y limosnas de cada convento" ${ }^{52}$.

Sin embargo, la enfermedad del papa Inocencio XIII trastocó los planes de Belluga, ya que la reunión de la Congregación que estaba prevista para esa semana y decidir sobre los puntos referentes a los regulares se aplazó hasta después

50. Ibid., leg. 4805. Belluga a Grimaldo. Roma, 3 de octubre de 1722. La bula de reforma había sido solicitada por el rey y por los arzobispos de Toledo, Santiago, Sevilla, Burgos y Zaragoza, y diecisiete sufragáneos de los dos últimos. En ibíd. Roma, 22 de septiembre de 1722, Belluga dice a Grimaldo que había conseguido la extensión del rezo de san Isidoro para toda la Iglesia, y para España de san Leandro y su hermano san Fulgencio, patrono de su diócesis y de Plasencia.

51. Ibid., leg. 4805. Belluga a Grimaldo. Roma, 28 de noviembre de 1722.

52. Ibíd. Belluga a Grimaldo. Roma, 28 de noviembre de 1722. 
de Navidad para escuchar mientras tanto las alegaciones de los superiores regulares, a fin de que no pudieran decir que no los habían oído. Belluga no tuvo más remedio de condescender y retrasar el viaje, porque la Congregación se negó a retirar del proyecto de reforma los artículos referentes al clero regular, informando previamente a los prelados para que aceptasen y ejecutasen la bula, aunque no fuera de dogma sino de disciplina ${ }^{53}$.

Por otra parte, como a juicio de los médicos, la enfermedad del papa era muy grave y se temía por su vida, Belluga no sabía si debía quedarse hasta que se aclarase la situación o volver en cuanto concluyera el tema de la bula. Porque, aunque le preocupaba su diócesis, que estaba sin obispo desde hacía más de dos años, si moría el papa no tenía medios para hacer frente a los crecidos gastos del cónclave, y pidió ayuda para poder afrontarlos, a la vez que lamenta y se arrepiente de haber aceptado el capelo que le había causado tantos problemas y amarguras, con perjuicio de su diócesis y de sus fundaciones, y las mortificaciones que había tenido que sufrir desde hacía cinco meses,

el ver el abandono con que se me ha tratado, como si yo hubiese hecho algún gran mal o faltado en algo al cumplimiento de mi obligación, pues a un mal criado que S. M. tuviera en esta Corte no me parece se le podía tratar en la forma que yo he experimentado. No se admire que me explique así, porque me hace tanta fuerza el considerar que ningún otro cardenal que hubiese venido aquí, enviado por S. M. y que estuviera detenido en cosas de su servicio, se le hubiera tratado de esta forma. Y me lastima tanto el corazón el pensar que todo es deseo del mayor bien de SM y honor de la nación, que por la misericordia de Dios me he mantenido aquí, que no se debe admirar de que explique algo de lo que siento ${ }^{54}$.

Una vez que se reunió la Congregación y aprobó los puntos de reforma de ambos cleros, tanto del secular como del regular, el cardenal Acquaviva pidió al pontífice, en nombre del rey, que despachase una bula con los artículos que había que reformar para que nadie pudiera reclamar. Pero Inocencio XIII se mostró reticente y le contestó que el rey no haría esta petición si hubieran llegado a sus oídos los clamores de los regulares y las instancias de muchos obispos contra la bula,

que creen perjudicial a su decoro el que se diga que sus diocesanos necesitan de reformas y nuevas bulas para la ejecución del concilio de Trento, cuando ellos creen que en todo se cumple con exactitud, y han llegado a decir que si Belluga tiene esta necesidad en su diócesis que la remedie por sí mismo, como hacen los demás, sin pasar a estas novedades tan ridículas ${ }^{55}$.

53. Ibid. Belluga a Grimaldo. Roma, 5 de diciembre de 1722; y leg. 4804. Acquaviva a Grimaldo. Roma, 5 de diciembre de 1722 .

54. Ibíd. Belluga a Grimaldo. Roma, 5 de diciembre de 1722.

55. Ibid., leg. 4808. Acquaviva a Grimaldo. Roma, 10 de abril de 1723. 
Después de la audiencia con el papa, Acquaviva salió con la convicción de que el despacho de la bula no lo haría tan pronto como Belluga creía, y que el papa se limitaría a expedir un breve confirmatorio de las resoluciones aprobadas por la Congregación, dejando libertad para recurrirlo a los que se sintieran agraviados $^{56}$. El 13 de mayo el papa firmó la bula, y el día 20 Belluga se puso en camino para España, llevando consigo el Breve de la reforma del estado eclesiástico en Españ ${ }^{57}$, aunque él siempre habla de bula y el nuncio unas veces dice breve y otras bula ${ }^{58}$. El agente de preces, Félix Cornejo, es más preciso y dice que no es bula, "como se ha pretendido", sino breve, con la cláusula de que cualquiera pueda recurrir a la Congregación del Concilio su contenido, mientras que las decisiones de una bula no se pueden impugnar.

Y así se han valido del expediente del breve -dice Cornejo-, persuadiendo a Belluga que tiene la misma fuerza que la bula. Pero fuera de aquellos pocos que le han querido persuadir que tendrá efecto su deseo, se cree generalmente que con poca diferencia se quedaran en su mismo estado las materias que ha promovido [...]. Pues estos procuradores generales de las religiones, que se han opuesto siempre a lo que ha solicitado el cardenal, con las facultades que les da el breve no dejarán de la mano esta materia, y esta consideración ha hecho que no se expida la bula, por no exponerse a suscitar alguna inquietud en España, respecto que contra las decisiones de la bula no se puede replicar sin que primero lo permita el $\mathrm{papa}^{59}$.

El documento pontificio centra la atención en la reforma de ambos cleros, el secular y el regular, y se limita a reavivar las exigencias tridentinas, sin acometer la reforma de raíz. Porque, aunque Belluga pensaba que sería un remedio eficaz para corregir los abusos del clero, Félix Cornejo creía, con la mayoría de los curiales, que tendría poco efecto y las cosas quedarían más o menos como estaban $^{60}$. Unos días después, Cornejo remitió un ejemplar del breve Sanctissimi $D$. N. Domini Innocentii divina providentia papae XIII, Apostolicae litterae super ecclesiastica disciplina in regnis hispaniarum, acompañado de ciertos decretos que en diferentes tiempos se habían formado sobre la reforma del clero, afirmando una vez más "que los que entienden de las materias y puntos de que trata dicho breve dicen que no concluye cosa alguna, y que antes bien deja plantada (así lo

56. Ibid., leg. 4813. Acquaviva a Grimaldo. Roma, 8 de mayo de 1723.

57. Ibid., leg. 4808. Acquaviva a Grimaldo. Roma, 22 de mayo de 1723. Le envía una copia impresa del breve.

58. Archivio Apostolico Vaticano (en adelante AAV), Segr. Stato, Spagna, vol. 223, ff. 250, 369 y 386. Aldobrandini a Spinola. Madrid, 19 de junio y 4 y 11 de septiembre de 1723.

59. AGS, Estado, leg. 4811. Cornejo a Grimaldo. Roma, 15 de mayo de 1723.

60. En ibídem hay un ejemplar impreso en latín de la Carta Apostólica de Inocencio XIII sobre la disciplina eclesiástica en los reinos de España. Roma, 1723. Una copia en castellano en TEJADA y RAmiro, Juan. Colección completa de los concordatos españoles. Madrid: Imprenta Pedro Montero, 1862, pp. 83-93. 
expresan ellos) una riña que frute bastantemente a estos tribunales por los pleitos que suscitará» ${ }^{61}$.

Belluga, una vez que estuvo en posesión del documento pontificio, se dispuso para volver a España y entregárselo al rey. El 20 de mayo de 1723 emprendió el camino hacía Génova por tierra y, al llegar a Livorno, se embarcó hasta Génova. Pero padeció tanto en el trayecto que decidió hacer el viaje por tierra después de terminar de tomar los baños. Sin embargo, a pesar de afirmar que se había despedido del mar para toda su vida, aunque tuviera que sufrir duros trabajos si hacía el camino por tierra, el 12 de junio la República de Génova le ofreció puesto en una galera para llevarle hasta Alicante y aceptó ${ }^{62}$.

El 18 de julio llegó a la Corte y pidió licencia para pasar al Real Sitio de Valsaín y poner en manos del rey la bula original y justificar su estancia en Roma, trasladándose a su obispado una vez que el rey tomase las providencias que juzgase más convenientes para la ejecución de la bula. Sin embargo, no llegó a pasar al Real Sitio, sino que entregó la bula al padre Daubenton para que se la diera al rey, junto con un papel para su ejecución. Pero, como el padre confesor murió el 7 de agosto, comunicó a Grimaldo que la bula y el papel para su ejecución estaban en un cofre que el secretario del confesor iba a llevar a Valsaín con otros documentos, y le rogó que entregase al rey la bula y el papel que iba con ella, "todo con la aprobación del confesor", y lo enviase al Consejo para que concediese el pase regio para su ejecución.

Conviene -dice el papel- que S. M. mande enviar al gobernador del Consejo la bula original con algunas copias de las impresas para que se vea en Consejo Pleno, y se reconozca si la bula ha satisfecho el real ánimo y el deseo que explicó a los arzobispos y obispos en orden a la reforma de la disciplina de uno y otro clero, cuando los excitó a la celebración de los concilios provinciales por su real carta, en cuyo lugar de los dichos concilios provinciales se subroga esta bula, como medio más eficaz para la reforma de los puntos más necesitados de remedio de ambos $\operatorname{cleros}^{63}$.

Poco después, la bula pasó al Consejo para su revisión, pero lo que parecía un mero trámite se convirtió en un calvario para Belluga por las dificultades y observaciones que pusieron los consejeros. El cardenal trató de aclarar las dudas, afirmando que todo su contenido estaba en el concilio de Trento, pero el fiscal continuó poniendo objeciones ${ }^{64}$. Ante la demora del Consejo en conceder el pase para su ejecución, Belluga se quejó a Grimaldo de la ojeriza que habían tomado los consejeros «a la que llaman bula mía, sin hacerse cargo de todo lo que ha

61. AGS, Estado, leg. 4811. Cornejo a Grimaldo. Roma, 22 de mayo de 1723.

62. Ibíd, leg. 4813. Belluga a Grimaldo. Génova, 2, 8 y 12 de junio de 1723.

63. Ibid., leg. 4810. Belluga a Grimaldo. Madrid, 8 de agosto de 1723.

64. AAV, Segr. Stato, Spagna, vol. 223, ff. 369, 386, 415, 424, 444, 489 y 509. Aldobrandini a Spinola. Madrid, 4 y 11 de septiembre, 2, 9 y 23 de octubre, 20 de noviembre y 4 de diciembre de 1723. 
pasado en esta materia, ni de su importancia, y que Su Majestad la tenía pedida a Su Santidad ${ }^{65}$.

Por fin, en noviembre de 1724 el Consejo dio el pase regio para su promulgación y se enviaron ejemplares a los obispos y prelados regulares para su observancia $^{66}$. Pero con su promulgación se hicieron realidad los temores del papa, y se desencadenó un movimiento de oposición desproporcionado por parte de los regulares, que presentaron al rey un memorial para que impidiese su ejecución "por los notorios perjuicios contra sus exenciones y el inminente riesgo de disturbios que temían si se ponía en práctica». Se respondió que, como ya se había publicado, no se podía impedir su circulación, por lo que los religiosos presentaron al rey otra súplica para que interpusiera su ayuda a fin de que el papa suspendiera su ejecución ${ }^{67}$. A la protesta de los regulares se sumó la de los cabildos catedralicios ${ }^{68}$ y el disgusto de los regalistas, que consideraban que el breve no resolvía los problemas planteados y no juzgaban necesaria la intervención romana para resolver las deficiencias morales de la Iglesia española. Aunque el papa no escuchó a los regulares y publicó una constitución confirmatoria de la bula ${ }^{69}$, y el rey recomendó su observancia, solo se pudieron aplicar algunos puntos sobre el reclutamiento y formación del clero secular, pero la mayor parte de las disposiciones no se llegaron a ejecutar.

Lo cierto es que, además de las protestas que provocó la bula y su escasa ejecución, el documento pontificio no abordaba la raíz del problema, que consistía en la excesiva facilidad con que la Curia romana concedía dispensa de los preceptos disciplinares y en la deficiente elección de las personas que ocupaban los beneficios eclesiásticos ${ }^{70}$. En el fondo seguían en pie muchas corruptelas que, a juicio de los regalistas, eran apoyadas por la Curia por intereses económicos o jurídicos, pero que incidían perniciosamente en la decadencia del clero, fomentando o al menos encubriendo los abusos, como eran las pensiones, reservas y

65. AGS, Estado, leg. 4813. Belluga a Grimaldo. Madrid, 5 de diciembre de 1723.

66. AAV, Segr. Stato, Spagna, vol. 224, f. 350. Aldobrandini a Paolucci. Madrid, 25 de noviembre de 1724 .

67. Ibid., vol. 225, ff. 172-173. Aldobrandini a Paolucci. Madrid, 28 de abril de 1725; y Memorial presentado a la majestad del Señor Rey D. Felipe V por las religiones, así monacales como mendicantes, en vista del breve de su Santidad, publicado por VAlLADARES, Antonio. Semanario erudito, IX. Madrid: Blas Román, 1788, pp. 143-205.

68. Memorial de la Iglesia de Toledo contra la bula Apostolici ministerii, publicado por FuENTE, Vicente de la. Historia eclesiástica..., op. cit., p. 336. A los que se pueden sumar los memoriales que se custodian en la BEESS, ms. 73, ff. 80-117. Suplex libelus Benedicto XIII oblatus ab archiepiscopis et episcopis regnorum Hispaniarum, Romae, 1727; y ff. 118-138. Memoriale dato a nome delli capituli delle Sante Chiese di Castiglia e Leone alla Maestà del Rè Cattolico, con quello gli fu presentato, diretto a sua Santità, s. f. 1726.

69. AAV, Segr. Stato, Spagna, vol. 226, f. 150. Aldobrandini a Paolucci. Madrid, 4 de mayo de

70. SÁNCHEZ DE LAMADRID, Rafael. El concordato español de 1753 según los documentos originales de su negociación. Jerez de la Frontera: Tipografía de Jerez, 1937, pp. 121-122. 
coadjutorías con derecho a sucesión, que se prestaban a una serie de abusos que irritaban a gran parte del episcopado y de manera especial a los anticurialistas partidarios de la reforma. El problema de tales abusos subyace en las polémicas regalistas de la década del 1730, en estricto paralelismo con la defensa del patronato real, y el intento de resolverlos quedó patente en el concordato de 1737. Pero este concordato tampoco terminó con los abusos ${ }^{71}$, y el de 1753 marginó el problema de la reforma del clero, aunque dejó abierto el camino para que los intentos de reforma partieran de España y aumentara el control de la Iglesia por parte del monarca.

\section{VUELTA A ESPAÑA Y RENUNCIA AL OBISPADO}

Aunque al final del verano de 1721 Belluga había dicho al padre Daubenton que le agradaba la idea de quedarse en Roma de forma definitiva, renunciando el obispado o dándolo en coadjutoría, siempre que el rey lo aceptase y le asignase la congrua necesaria para poder mantenerse en la Corte romana, poco después, le comunicó que no congeniaba con el cardenal Acquaviva y no quería permanecer en Roma, de forma que, si los navíos que habían enviado para recoger al cardenal Borja y a él no llegaban hasta finales de noviembre o primeros de diciembre, se podría ir con ellos, porque para entonces esperaba tener solucionada la reforma del clero que estaba gestionando. Pero, si llegaban en octubre o primeros de noviembre, no podría marcharse porque no estaría concluida la reforma por la parsimonia con que los curiales gestionaban los negocios. Por eso, cuando llegasen los navíos escribiría al comandante Serrano y al conde de Clavijo para que, si era posible, dejasen una embarcación hasta finales de diciembre y así evitar el gran coste que supondría ir en los navíos de Malta.

Por esto pido -dice Belluga- que se detenga uno de los navíos, porque si me llevan los navíos de Malta, llevando a toda mi familia, ropa y un coche, y manteniéndome, es preciso hacer al comandante un regalo de 400 o 500 doblones, Y además de esto, como el viaje en los navíos del Malta no podría ser hasta abril o mayo se me aumentará el gasto en esta ciudad, con el que ahora se me acrece por hacer muchas libreas de invierno a todos los lacayos, cocheros y ayudas de cámara, lo que yo ignoraba, y es un gasto muy crecido con otros de la propia persona, y con lo que ya estoy empeñado, aunque cobre la letra, si no me voy en diciembre en los navíos de S. M. no me podré mantener aquí hasta abril y costear el viaje a España, pagar la casa que tengo, pagar a los judíos las alhajas, hacer un regalo decente al monasterio y otros gastos indispensables ${ }^{72}$.

71. Mestre, Antonio. "La Iglesia y el Estado. Los concordatos de 1737 y 1753». En Historia de España (Menéndez Pidal-Jover), XXIX/1. Madrid: Espasa-Calpe, 1985, pp. 279-333; BARRIO GOZALO, Maximiliano. La embajada de España en Roma..., op. cit., pp. 61-68.

72. AGS, Estado, leg. 4799. Belluga a Daubenton. Roma, 19 de octubre de 1721. 
Medio año después, al no recibir contestación ni el socorro solicitado, Belluga pensó que provenía de la proposición que había hecho al confesor real de quedarse en Roma, dando en coadjutoría el obispado. Por ello, para aclarar las dudas sobre su pretensión, el 18 de abril de 1722 escribió a Grimaldo una larga carta explicando los motivos que tenía para dejar el obispado y retirarse a un monasterio en 1728, una vez que celebrase sínodo diocesano y dejase arreglado el tema de las pías fundaciones. Sin embargo, la concesión del capelo hacía imposible el retiro que deseaba, porque si no servía su iglesia particular debía servir la universal en Roma. Aunque el trabajo de la Curia era mayor que el del obispado, estaba libre de los escrúpulos que llevaba consigo el cargo de las almas; por eso, cuando llegó a Roma comenzó a pensar quedarse en la Corte romana y renunciar el obispado, sin dejar de la mano las fundaciones y asegurar la congrua necesaria para mantenerse en ella.

Y haciéndome siempre embarazo a los discursos la dicha donación que tenía hecha de los frutos de Cartagena para las fundaciones con cesión que hice a la Junta de gobierno de ellas por ocho años, los que se cumplen como llevo dicho el 28, no pudiendo dejar de continuarse esta donación por dicho tiempo, por ser así necesario, para poner en perfección las obras en las tierras de dichas fundaciones, las que de aquí a 14 o 15 años pueden dar los réditos anuales de 50.000 pesos, y con el tiempo muchísimo más, creciendo las arboledas de moreras que se han empezado a poner, conociendo que dicha cesión no se podía componer con mi suficiente congrua, por no saber yo entonces lo que diré después pueden hacer en orden a la congrua de los cardenales, discurrí el medio de la coadjutoría, que escribí a S. M. por el tiempo que durase la cesión, para renunciar luego al obispado, reservándome la mitad de los frutos, sacadas las cargas, si se dignaba S. M. por dicho tiempo completarme la congrua ${ }^{73}$.

Poco después, antes de recibir la respuesta, como consecuencia del incidente que tuvo con el embajador Acquaviva por la visita que había realizado al cardenal del Giudice y otros motivos, escribió al confesor real que no convenía llevar adelante sus proposiciones. Sin embargo, cuando fue conociendo a los cardenales y su estilo de vida, descubrió que al que quería vivir al margen de las vanidades que propiciaba la vida cortesana nadie se lo impedía, siempre que guardase la decencia que exigía la dignidad cardenalicia, y volvió a sentir deseos de quedarse en Roma, renunciando al obispado, dado que no se aceptaba que lo diese en coadjutoría.

Ante la necesidad de tomar una decisión, viendo que algún día debía dejar el obispado y venir a servir la dignidad cardenalicia con el incómodo y riesgo del mar, que tanto le maltrataba, y considerando también que la Corte romana no podía estar sin un cardenal español para las mil cosas que se ofrecían en las congregaciones, «en que no hay quien dé razón ni dé a entender lo que se trata

73. Ibíd., leg. 4805. Belluga a Grimaldo. Roma, 18 de abril de 1722. 
o pide», como sucedía muchas veces en las visitas ad limina de los prelados, en los recursos de regulares y en otros muchos negocios. Después de consultarlo y enterarse de que la renuncia de los cardenales que eran obispos no requería más causa que desear vivir en Roma para servir a la Santa Sede, y que podía reservarse lo que necesitase para su congrua de las rentas de la mitra y seguir disfrutando del indulto de proveer los beneficios eclesiásticos en la diócesis que dejaba durante los meses apostólicos, dijo a Grimaldo que, si el monarca daba su consentimiento y le prometía completarle la congrua con pensiones o beneficios, quería quedarse en Roma y renunciar el obispado en la forma que contenía el despacho de renuncia que adjuntaba, pero imponiendo cuatro condiciones que, al menos de hecho, le permitían seguir controlando las rentas de la mitra ${ }^{74}$ :

1. Conservar el indulto cardenalicio de proveer beneficios eclesiásticos en los ocho meses apostólicos, en la forma que lo había concedido el papa Urbano VIII.

2. Nombrar, mientras viviera, a la persona que se encargase de administrar los frutos y rentas del obispado de Cartagena, y designar al tesorero que recibiese su importe, del cual se debían pagar en primer lugar las cargas de aquel obispado y las pensiones, que montaban al año 57.905 reales de vellón. Al obispo que le sucediese en el obispado se le debía entregar 132.000 reales para su congrua, libres de toda carga, mitad en junio y mitad en diciembre de cada año.

3. Para la congrua del dicho cardenal Belluga se habían de pagar otros 132.000 reales, libres de todas cargas y gastos de conducción a la Corte romana.

4. Finalmente se habían de deducir 75.000 reales para entregar, mientras viviera el cardenal, a disposición de los administradores generales de las fundaciones que había erigido en aquel obispado. Y, después de hechas todas las deducciones, las cuales sumaban 396.753 reales de vellón, el remanente, que según el último quinquenio importaba 42.247 reales, debía servir para los gastos de recolección, administración y conservación de los frutos y otros que expresaba. Y si algún año no llegaban las rentas del obispado a la referida suma y no se podía satisfacer íntegramente la porción asignada a las fundaciones, se contribuiría con la cantidad que alcanzase, abonando el déficit en los años siguientes en que excediese la renta ${ }^{75}$.

74. AHN, Consejos, leg. 16997. Consulta de la Cámara, 25 de abril de 1724.

75. Ibídem. Cf. Barrio Gozalo, Maximiliano. El Real patronato y los obispos españoles del Antiguo Régimen (1556-1834). Madrid: Centro de Estudios Políticos y Constitucionales, 2004, pp. 186-187; MARTínez Ripoll, Antonio. "Regalismo borbónico, reformismo eclesiástico...», op. cit., pp. 47-49, habla de las cuatro condiciones impuestas por Belluga para renunciar, pero no describe todo el proceso hasta la definitiva concesión de Felipe $\mathrm{V}$, los reparos de la Curia y la aprobación de la renuncia por el papa. 
Además, como en el documento de la renuncia no lo podía indicar, añade que necesitaba para vivir en Roma al menos 10.000 escudos romanos cada año, «y serán poquísimas las limosnas que puedo hacer, ya que para hacer las debidas necesito de 13 a 14.000». Pero, como los 132.000 reales que recibiría de las rentas de la mitra de Cartagena solo sumaban 7.000 escudos romanos, faltaban otros tres mil para completar su congrua ${ }^{76}$.

La renuncia de Belluga pasó a consulta de la Cámara de Castilla, que puso reparos por reservarse la mitad de la renta de la mitra para su congrua sustentación, de lo que no había ejemplares. Por ello se remitió el negocio al fiscal para que diera su dictamen. El fiscal aceptó que tenía facultad para renunciar, si quería residir en Roma, pero puso dos reparos a la renuncia que había presentado. Primero, que se reservase una pensión moderada, de acuerdo con los frutos de la mitra, regulando el valor líquido que pudiera quedar hasta finales de 1727, fecha en que concluía la cesión de un tercio de la renta que tenía hecha a favor de las pías fundaciones. Y segundo, que, en cuanto a reservarse la provisión de los beneficios, se debía entender los que vacasen en los ocho meses apostólicos, no en los cuatro ordinarios, pues de lo contrario se haría un gran agravio al nuevo obispo.

En vista del dictamen del fiscal, la Cámara acordó que se revisase lo que se había hecho en las renuncias de los cardenales Spinola, Sandoval y Pimentel cuando marcharon a Roma, para ver si algún caso se adaptaba al presente. Se descubrió que en 1637 Felipe IV había asignado a Spinola y Sandoval 24.000 ducados de plata a cada uno para su congrua sustentación, "por haber renunciado en Roma sus iglesias y residir en aquella Corte». Después les ofreció aumentar la asignación hasta los 38.000 ducados en rentas eclesiásticas, pero no se pudo llevar a cabo. Con estas noticias el fiscal volvió a insistir en su anterior respuesta, oponiéndose a la renuncia con la reserva de la mitad de los frutos del obispado de Cartagena y la facultad de nombrar administrador y tesorero para su percepción y distribución, pues esto no era una simple renuncia, ya que seguía percibiendo los frutos con propia autoridad y en detrimento del nuevo obispo.

Ante el dictamen del fiscal, la Cámara dictaminó que el cardenal Belluga renunciase lisa y llanamente, como lo hacían todos los prelados que solicitaban el real asenso para hacerlo, y que Su Majestad le asignase para su congrua sustentación la cuarta parte del valor liquido del obispado de Cartagena, bajadas las cargas y gastos de administración, y se mantuviera la obligación temporal que tenía hecha a favor de las obras pías hasta finales de 1727. Y por lo tocante a conferir beneficios, lo podía hacer en los meses apostólicos. El confesor real se conformó con el dictamen de la Cámara, y también lo hizo el rey el 13 de octubre ${ }^{77}$.

76. AHN, Consejos, leg. 16997. Consulta de la Cámara, 25 de abril de 1724.

77. AGS, leg. 4805. Dictamen de la Cámara sobre la renuncia de Belluga, 28 de septiembre de 1722. 
Mientras tanto, Belluga recibió los dos mil doblones que le mandaron para el viaje. Pero, a la vez que dio las gracias a Grimaldo, aprovechó la ocasión para decirle que había echado cuentas y era imposible mantenerse en Roma con diez mil escudos, porque estaba todo muy caro y había tantos pobres en Roma que sería escandaloso dejar de darles limosna, como hacían los obispos de España. Pero, si ellos podían hacerlo con dos mil escudos, él necesitaba cuatro mil, necesitando otros ocho mil para sus gastos ${ }^{78}$.

Cuando acababa de escribir la carta anterior, recibió la resolución real del 16 de octubre sobre su proyectada renuncia, en la cual se le comunicaba que el rey, de acuerdo con el dictamen de la Cámara, solo aceptaba la renuncia con la reserva de la cuarta parte del valor líquido del obispado, bajadas las cargas y gastos de administración, más la cesión que tenía hecha a favor de las obras pías. El mismo día Belluga contestó a Grimaldo que, como la tercera parte del valor líquido del obispado no era suficiente para la congrua necesaria en la Corte romana, entendía que la resolución del monarca insinuaba que no quería que se quedase en Roma. Por lo tanto, como no pretendía otra cosa que hacer la voluntad de Dios y del rey, seguiría con la cruz de su obispado y en los primeros días de enero se pondría en camino para volver a España ${ }^{79}$.

Como el tiempo iba pasando y la cuestión de la renuncia seguía estancada, el 13 de febrero de 1723 el cardenal escribió una larga carta a Grimaldo, comunicándole que el despacho de la Cámara, al rechazar las condiciones propuestas en la renuncia y decirle que debía hacerla de forma lisa y llana, daba a entender que el rey no tenía interés en que se quedara en Roma y había decidido volver a su obispado en el mes de enero. Pero, después de tomar esta la decisión, el papa sufrió un grave incidente que hizo temer por su vida, y comunicó al monarca que temía que esto retrasase el viaje a su diócesis, como había comunicado, a pesar de sus escrúpulos de conciencia por tener abandonado su obispado desde hacía dos años y medio. No obstante, por servir al rey, aceptaba permanecer en Roma mientras durase la enfermedad del papa ${ }^{80}$.

Grimaldo le respondió que podía quedarse en Roma hasta ver la evolución de la enfermedad del papa y le enviaría dinero para su sustento, pero no le aclaró ninguna de las dudas que había planteado sobre la necesidad de volver a España para residir en su obispado, al no haber aceptado la renuncia como la había presentado $^{81}$. Belluga respondió que estaría en Roma hasta que le mandasen y estuviese terminada la bula de la reforma del clero, una vez que el rey no había aprobado su renuncia para quedarse definitivamente en la Corte romana ${ }^{82}$.

\footnotetext{
78. Ibid. Belluga a Grimaldo. Roma, 28 de noviembre de 1722 .

79. Ibid. Belluga a Grimaldo. Roma, 29 de noviembre de 1722.

80. Ibíd., leg. 4813. Belluga a Grimaldo. Roma, 13 de febrero de 1723.

81. Ibíd. Grimaldo a Belluga. El Pardo, 15 de enero de 1723.

82. Ibíd. Belluga a Grimaldo. Roma, 20 de febrero de 1723.
} 
Sin embargo, el purpurado se enteró por otros conductos oficiosos que el rey aprobaba su propuesta de quedarse en Roma y no había más reparo que las condiciones que había incluido en la renuncia, sobre todo, el querer reservarse la mitad de los frutos de la mitra, por lo que se le pedía que la hiciese de forma lisa y llana, dejando a la decisión del monarca tanto la adjudicación de la congrua como las otras peticiones que hacía. Pues el rey no se oponía a la cesión de parte de los frutos de la mitra para su congrua, ni a la reserva del indulto cardenalicio en los meses apostólicos, ni tampoco al sujeto que proponía para sucederle en el obispado. Por ello le aconsejaron que enviase la renuncia de forma lisa y llana, porque el rey accedería a muchos de sus deseos y él terminaría con sus angustias, una vez que quería dejar de ser obispo y poder servir al rey en Roma, "con quietud y seguridad de mi conciencia». En consecuencia decidió enviar la renuncia llana y lisa, aunque confiesa que no podía ser llana por las cláusulas de tipo económico y jurisdiccional que debía incluir.

Lo primero -dice Belluga-, no puedo quedarme en Roma sin tener asegurada a lo menos la congrua de 10.000 escudos romanos, y estaré siempre estrecho y sin poder hacer aquellas limosnas que debe hacer un cardenal, porque los 8.000 son necesarios, sin dar un ochavo de limosna, para mantenerse con decencia en esta Corte y pagar casa, y esta es la regla general aquí de todos los cardenales que viven con moderación, y los que en rentas eclesiásticas no los tienen los suplen de su patrimonio, con que solo restan dos mil escudos para limosna, y en un cardenal español es nada solo para los españoles y familias que aquí hay desamparadas de muchos oficiales y otras personas de cuenta, que han muerto en servicio del emperador y están aquí cargadas de hijos, sin los pobres dispensantes, que van y vienen, que fuera impiedad acudir a un cardenal español y no socorrerlos.

Esto supuesto, debo decir que el consignar en el obispado la mitad de los frutos para parte de la congrua, como tengo expresado en un quinquenio, son siete mil escudos, y es porque de otra forma S. S. no admitiría la renuncia, porque no la puede admitir sino quedando al cardenal congrua perpetua, de lo que tiene V. M. ejemplar en las respuestas de S. S. a la renuncia del cardenal Alberoni, respecto a las proposiciones que se han hecho sobre el obispado de Málaga.

La dificultad que parece se le ofrece a la Cámara para que no sea la mitad de los frutos, sino la cuarta parte, es que no le quedará al obispo con que mantenerse, y suponiendo que no le quedara todo lo que yo quisiera para socorrer con abundancia a los pobres debo decir que con siete mil escudos libres de cargas y gastos fijos, estos importan 12.000 ducados y hay muchos obispados donde se requiere igual decencia que en Murcia que no tienen diez mil ducados libres, como son Valladolid, Salamanca, León, Oviedo, Cádiz y Badajoz, y otras ciudades semejantes, y se mantienen los obispos dando la poca limosna que pueden ${ }^{83}$.

Por las razones expuestas la renuncia no podía ser llana, ya que debía contener también la porción consignada para las fundaciones y la reserva de los ocho

83. Ibíd., leg. 4813. Belluga a Grimaldo. Roma, 13 de febrero de 1723. 
meses que concedía el indulto cardenalicio. Y como la renuncia debía incluir, como algo indispensable, las tres condiciones de la congrua, consignación de las fundaciones y reserva del indulto, no podía, aunque quisiera, enviar la renuncia de forma lisa y llana. Por ello, lo dejaba en las manos del rey, como había hecho en lo referente a los tres mil escudos anuales que había solicitado que le asignase, sin cuya oferta no podía renunciar, porque sin ellos no podía mantenerse en Roma. Suplica también que se elija por sucesor en Cartagena a José Guerrero y Humanes, doctoral de la catedral de Murcia, por su capacidad para el ministerio y llevar adelante las fundaciones. Ante estas condiciones, pidió a Grimaldo que el rey le indicase lo que juzgase más conveniente: quedarse permanentemente en Roma o no tener ninguna utilidad para su servicio.

Pero ruego -dice Belluga- tenga a bien de darme el consuelo de que yo no muera obispo en ejercicio y que logré esta oportuna ocasión de hallarme ya en Roma para salir de esta carga tan pesada, y pido se me responda a vuelta de correo para que pueda hacer mi viaje por tierra, porque mi complexión y costumbre que tengo de muchos años de bañarme desde primeros de junio casi todos los días, por pedirlo así mi complexión, se me imposibilita el viaje que es de dos meses, no haciéndolo en este tiempo. Y porque mi conciencia no sufre, habiendo de quedar obispo, estar más tiempo ausente de mi obispado no quiero exponerme a riesgo tan grande como lo fuera de comenzar el viaje más tarde, exponiendo mi conciencia a una ofensa a Dios por faltar a mi residencia ${ }^{84}$.

A pesar del retraso del ir y venir los correos y la oposición de la Cámara a aceptar la renuncia con las exigencias que proponía, Belluga volvió a la carga, afirmando que antes de ser creado cardenal tenía dispuesto dejar el obispado por la debilidad de sus fuerzas, tener 60 años y haber gobernado durante dieciocho años el obispado de Murcia, y ahora la bula de Inocencio X le permitía renunciar el obispado para servir la dignidad cardenalicia y residir en Roma. Por ello, para hacer efectivo su deseo de dejar el obispado y vivir en Roma para cumplir la obligación de cardenal, renunciaba el obispado de Cartagena en manos de Inocencio XIII en la forma que el derecho le permitía, y enviaba la renuncia al rey para que pusiera las condiciones que tuviera a bien y la enviase al papa para su aprobación $^{85}$.

Dos meses después, ante las necesidades que había en su obispado por la continua falta de lluvia y la esterilidad de los campos por sexto año consecutivo, sintió grandes escrúpulos por no estar en la diócesis para socorrer a los más necesitados. Por esta razón y para ver el estado de su renuncia decidió volver a su diócesis para ayudar a los necesitados, componer las diferencias que habían surgido en el cabildo con el provisor y los gobernadores, consolidar las fundaciones y regularlas de forma completa para dejarlas en manos del nuevo obispo con las

84. Ibidem.

85. Ibíd. Belluga a Grimaldo. Roma, 20 de febrero de 1723. 
prevenciones convenientes. En consecuencia, el 17 de abril comunicó a Grimaldo que había decidido ponerse en camino a finales de mes, llevando la bula de la reforma del clero, que el romano pontífice le había dicho que la expediría antes de marcharse, advirtiendo al cardenal Acquaviva que, si durante su viaje, llegaba la renuncia y nominación del nuevo obispo, la retuviese hasta recibir nueva orden del rey. Haría el viaje por tierra e iría directamente a la Corte para besar las manos del rey, entregarle la bula y conocer su resolución sobre quedarse en Roma y el nombramiento del nuevo obispo, a fin de que no se dilatase más el negocio, tranquilizar su conciencia y satisfacer la necesidad de la diócesis ${ }^{86}$. Unos días después volvió a insistir en lo mismo, afirmando que esperaría unos días antes de despedirse del papa, por ver si llegaban cartas de Madrid y saber si quedaba libre del obispado o debía ir a residirlo, porque el papa no hacía más que decir: "No se va, no se va, y con esto en más de un mes que ha pasado desde que tiene la bula, aún no la ha firmado, habiéndome dicho que antes de salir a su villaggiatura [vacaciones] la despacharía, pero sale pasado mañana y no lo ha hecho, bien es verdad que dicen no estará más de ocho días» ${ }^{87}$.

Antes de ponerse en camino, le llegó la carta con el recibo de su renuncia y sufrió una nueva decepción. Pues, cuando esperaba que el rey habría nombrado sucesor para aquietar su conciencia, Grimaldo le comunicaba que el monarca había mandado la renuncia a la Cámara para que diera su dictamen y, como este informe podía tardar cinco o seis meses, como el anterior, no pudiendo tener tanto tiempo abandonadas a sus ovejas, decidió volver sin dilación. Se despidió de los cardenales, informó al cardenal Acquaviva de su marcha «a quien mi resolución no dudo le será muy grata», y esperaba la audiencia del papa y el despacho de la bula, porque no podía ponerse en camino sin llevarla. Aunque no cerraba la posibilidad de volver a Roma, si el rey aceptaba las condiciones puestas a su renuncia, daba por bien empleado el viaje para componer las cosas de su obispado. Y, si el monarca rechazaba sus condiciones, se quedaría en su diócesis, remediando los males ocasionados por su larga ausencia, para que no se hiciesen mayores y más difíciles de remediar ${ }^{88}$.

En los primeros días de junio el embajador Acquaviva recibió la carta del rey para que presentase al papa la renuncia de Belluga a la iglesia de Cartagena con las cuatro condiciones que el monarca la había admitido, y al mismo tiempo presentase a José Guerrero Humanes, canónigo doctoral de la misma iglesia, para ocupar la silla episcopal de Cartagena. Pero, como para entonces Belluga ya se había puesto en camino para España, Acquaviva despachó un correo extraordinario a Génova, esperando que todavía se hallase en aquel puerto, ya que este retraso no causaba ningún perjuicio porque todavía no habían llegado los despachos con

86. Ibíd., leg. 4813. Belluga a Grimaldo. Roma, 17 de abril de 1723.

87. Ibíd. Belluga a Grimaldo. Roma, 24 de abril de 1723.

88. Ibíd. Belluga a Grimaldo. Roma, 8 de mayo de 1723. 
la presentación oficial del mencionado Guerrero para el obispado de Cartagena, sin los cuales no se podía hacer la presentación oficial ${ }^{89}$.

El cardenal Belluga se embarcó en Génova con buen tiempo y Acquaviva, en la última audiencia que tuvo con el papa, sabiendo que el purpurado le había informado con detalle acerca de la determinación del rey sobre su renuncia, se esforzó en interesar a Su Santidad sobre la misma. Porque, aunque no se ejecutaría hasta que el cardenal obtuviera algunas aclaraciones del rey, convenía ir allanando las dificultades que podía poner la Curia para que las conociese Su Majestad. La más importante era la imposición de siete mil escudos romanos de pensiones sobre la mitra, además de la tercera parte que se acostumbraba a imponer. Acquaviva adujo que había ejemplares de esto en las iglesias de España, siempre que el obispo nuevamente provisto quedase con congrua suficiente y pudiera pagar las pensiones impuestas, recordando el ejemplo cercano del obispo de Oviedo, que actualmente se hallaba en Roma recluido en un convento, al que se había señalado una pensión de dos mil escudos romanos sobre las rentas de la mitra para su sustento, por disposición del papa Clemente XI y con el consentimiento del rey, además de las pensiones existentes ${ }^{90}$.

Una vez que Belluga llegó a Madrid, envió al rey la renuncia al obispado de Cartagena lisa y llana, con la cláusula de que el monarca podía proponer al papa las condiciones que le pareciese oportuno. Una vez que el rey admitió la renuncia y presentó por sucesor del obispado a José Guerrero, Grimaldo envió al embajador Acquaviva la renuncia original, con la carta que el rey escribía al papa para que la presentase a Su Santidad y le propusiese las cuatro condiciones con que la había admitido: primera, que se asignen al cardenal Belluga diez mil escudos romanos para su congrua; segunda, que le conceda la mitad de las rentas del obispado de Cartagena, dejando la otra mitad para su sucesor, "que administrará las rentas y entregará al cardenal su mitad, en la inteligencia de que si no llega ésta a mas que siete mil escudos romanos, se ofrece S. M. a darle cada año tres mil escudos para completar la congrua»; tercera, que confirme las fundaciones hechas por el citado cardenal en su obispado; y cuarta, que permita al cardenal usar del indulto cardenalicio en los ocho meses apostólicos ${ }^{91}$.

El embajador Acquaviva entregó esta documentación al papa y, al ser revisada por la Curia, se pusieron muchas dificultades a las cláusulas que llevaba la

89. Ibíd., leg. 4809. Acquaviva a Grimaldo. Roma, 5 de junio de 1723.

90. Ibíd., leg. 4809. Acquaviva a Grimaldo. Roma, 26 de junio de 1723. José Fernández de Toro, nombrado obispo de Oviedo de 177, fue detenido por la Inquisición en 1710, procesado y declarado culpable. El obispo apeló al papa y fue trasladado a Roma en 1716. Se realizó un nuevo proceso que en 1719 ratificó la condena a reclusión perpetua en un monasterio, reservándole una pensión para su sustento sobre las rentas de la mitra. Cf. BARRIO GOZALO, Maximiliano. El Real patronato y los obispos..., op. cit., p. 175; TuÑón EsCALADA, Juan José. Corrientes espirituales en la España del siglo XVIII. El obispo de Oviedo Fernández de Toro. Madrid: Fundación María Cristina Masaveu Peterson, 2016, pp. $129-661$.

91. AGS, Estado, leg. 4813. Grimaldo a Acquaviva. Aranjuez, 8 de agosto de 1723. 
renuncia aprobada por el rey, lo que demoró su concesión casi un año. Por fin, el nuevo papa Benedicto XIII sancionó la renuncia el 11 de septiembre de 1724, cuando Belluga ya estaba en Roma, porque en el mes de abril se había puesto en camino para asistir al cónclave por la muerte de Inocencio XIII, en el que entró el 13 de mayo y participó en la elección de Benedicto XIII el 29 de mayo ${ }^{92}$. El 5 de agosto dirigió una carta pastoral de despedida a sus diocesanos ${ }^{93}$, y en Roma desempeñó diferentes encargos en la Curia y también al servicio del rey. Fue cardenal protector de la nación desde 1725 hasta su muerte; estuvo encargado de los negocios de la embajada durante el año 1732 y los cuatro primeros meses del siguiente año; intervino con el cardenal Troiano Acquaviva en las negociaciones previas al concordato de 1737 y en los tanteos que se hicieron al principio de los cuarenta que condujeron al de 1753. Falleció en Roma el 22 de febrero de 1743 y fue sepultado en la iglesia de Santa María in Vallicella, aneja a la casa central del Oratorio de San Felipe Neri, a la que dejo su biblioteca ${ }^{94}$.

\section{BiBLIOGRAFÍA}

BARRIO Gozalo, Maximiliano. «El clero bajo sospecha a principios del siglo XVIII. El informe de Macanaz y la respuesta de los obispos». Investigaciones Históricas, 2002, 22, pp. 47-62.

Barrio Gozalo, Maximiliano. El Real patronato y los obispos españoles del Antiguo Régimen (1556-1834). Madrid: Centro de Estudios Políticos y Constitucionales, 2004.

BARrio Gozalo, Maximiliano. "La Embajada de España en Roma principios del Setecientos. El cardenal Francesco Acquaviva y d'Aragona (1716-1725)». Roma Moderna e Contemporánea, 2007, XV, pp. 293-325.

Barrio Gozalo, Maximiliano. «El Cardenal Francesco del Giudice y el gobierno de la Monarquía, entre los Austrias y los Borbones». Cheiron, 2010, 53-54, pp. 327-366.

Barrio Gozalo, Maximiliano. El Clero en la España Moderna. Córdoba: CSIC-CajaSur, 2010.

BARRIO GOZALO, Maximiliano. "Monseñor Molines, ministro de Felipe V en Roma y conflicto de fidelidades (1709-1717)». Manuscrits. Revista d'Historia Moderna, 2017, 36, pp. 105-132.

BARRIO GozAlo, Maximiliano. La Embajada de España en Roma en la primera mitad del siglo XVIII. Madrid: Ministerio de Asuntos Exteriores y de Cooperación, 2017.

Benito Durán, Ángel. «Don Diego Muñoz y Vaquerizo, obispo de Segorbe, consejero de Felipe V». Boletín de la Sociedad Castellonense de Cultura, 1985, 61, pp. 19-31.

BENITO DurÁN, Ángel. «Don Luis Belluga y Moncada, cardenal de la Santa Iglesia y obispo de Cartagena, consejero de Felipe V». En CRemades GuiÑán, Carmen María (ed.). Estudios sobre el cardenal Belluga. Murcia: Academia Alfonso X el Sabio, 1985, pp. 137-210.

CANDAU CHACHÓN, María Luisa. La Carrera Eclesiástica en el siglo XVIII. Sevilla: Universidad de Sevilla, 1993.

92. Barrio Gozalo, Maximiliano. La embajada de España..., op. cit., pp. 198-201.

93. BEESS, ms. 393, ff. 137-148. Carta pastoral del Cardenal Belluga, obispo de Cartagena, a sus diocesanos ante la renuncia al obispado. Roa, 5 de agosto de 1724. Copia en italiano.

94. Barrio Gozalo, Maximiliano. La embajada de España..., op. cit., pp. 222-226. 
LA PRIMERA ESTANCIA DEL CARDENAL BELLUGA EN ROMA Y LA RENUNCIA AL OBISPADO...

Cardella, Lorenzo. Memorie storiche décardinali della Santa Romana Chiesa, VIII. Roma: Pagliarini, 1794.

CRIADO DEL VAL, Manuel. "El itinerario político del Padre Daubenton en la Corte de Felipe V». En Caminería Hispánica. Actas del VII Congreso Internacional Francia-España. Madrid: Casa Velázquez, 2004, pp. 1-24.

Desos, Catherine. Le vie du R. P. Guillaume Daubenton (1648-1723). Un jésuite français à la cour d'Espagne et Rome. Córdoba: Universidad de Córdoba, 2005.

EGIDO LÓPEZ, Teófanes. "El regalismo y las relaciones Iglesia-Estado en el siglo XVIII». En Historia de la Iglesia en España, IV. Madrid: BAC, 1979, pp. 162-173.

FERNÁNDEZ AlOnSO, Justo. "Un periodo de las relaciones entre Felipe V y la Santa Sede (1709-1717)». Anthologica Annua, 1955, 3, pp. 9-88.

FuENTE, Vicente de la. Historia eclesiástica de España, VI. Madrid: Impresores del Reino, 1875.

IRIGOYen LóPEZ, Antonio. Un obispo, una diócesis, un clero: Luis Belluga, prelado de Cartagena. Murcia: Academia de Alfonso X el Sabio, 2005.

Luis Belluga y Moncada. La dignidad de la púrpura. Murcia: CajaMurcia, 2006.

MarCos MarTín, Alberto. "Una mirada clerical a la España de comienzos del siglo XVIII. Los dictámenes de los obispos de 1715". En BERnardo Ares, José Manuel de, y MuÑOz MACHADO, Santiago (dirs.). El Estado-Nación en dos encrucijadas históricas. Madrid: Iustel, 2006, pp. 75-135.

MARTínEZ RIPOLL, Antonio. "Regalismo borbónico, reformismo eclesiástico y relaciones con Roma: el cardenal Belluga». En Alvar EzQuerra, Alfredo; Contreras, Jaime y Ruiz RoDRíGuez, José Ignacio (eds.). Política y cultura en la época moderna (cambios dinásticos, milenarismos, mesianismo y utopías). Alcalá de Henares: Universidad de Alcalá, 2004, pp. 29-50.

Mestre, Antonio. «La Iglesia y el Estado. Los concordatos de 1737 y 1753». En Historia de España (Menéndez Pidal-Jover), XXIX/1. Madrid: Espasa-Calpe, 1985, pp. 279-333.

Molina, Diego M. "La discusión en torno a la bula de Unigenitus». Archivo Teológico Granadino, 2009, 72, pp. 31-57.

Morgado García, Arturo. Ser clérigo en la España del Antiguo Régimen. Cádiz: Universidad de Cádiz, 2000.

PASTOR, Ludwig von. Historia de los papas en la época de la Monarquía absoluta, XXXIV. Barcelona: Gustavo Gili, 1937.

Rodríguez PomaR, F. «Una página de política española. Dictámenes de los prelados en 1715". Razón y Fe, 1941, 122, pp. 334-344; y 1942, 122, pp. 49-66.

SÁNCHEZ DE LAMADRID, Rafael. El concordato español de 1753 según los documentos originales de su negociación. Jerez de la Frontera: Tipografía de Jerez, 1937.

TejadA Y RAmiro, Juan. Colección completa de los concordatos españoles. Madrid: Imprenta Pedro Montero, 1862.

TuÑón EscaladA, Juan José. Corrientes espirituales en la España del siglo XVIII. El obispo de Oviedo Fernández de Toro. Madrid: Fundación María Cristina Masaveu Peterson, 2016.

Valladares, Antonio. Semanario erudito, IX. Madrid: Blas Román, 1788, pp. 143-205.

VILAR, Juan Bautista. El cardenal Luis Belluga. Granada: Comares, 2001.

VILAR, María José. «El Cardenal Belluga en Italia». En Luis Belluga y Moncada. La dignidad de la púrpura. Murcia: CajaMurcia, 2006, pp. 317-329.

VILAR, María José. «La misión oficial del cardenal Belluga en Roma en 1722-1723, a través de un epistolario inédito". Hispania Sacra, 2010, 65/125, pp. 243-265. 
